\title{
PEMBERDAYAAN CIVITAS AKADEMIKA PERGURUAN TINGGI UNTUK MEMBERIKAN SANTUNAN KE PANTI ASUHAN DI JAKARTA
}

\author{
Richard Andrew ${ }^{1}$ dan Michelle Claudia ${ }^{2}$ \\ ${ }^{1}$ Jurusan Manajemen, Universitas Tarumanagara Jakarta \\ Email:richarda@fe.untar.ac.id \\ ${ }^{2}$ Program Studi Sarjana Manajamen, Universitas Tarumanagara Jakarta \\ Email: michelle.115180329@stu.untar.ac.id
}

\begin{abstract}
Today, many things human can do to help others, especially those who are closed to us in our routine life. Giving some help is simple, from just giving a small amount of money to giving two day one night experience in a lifetime. Every cherishes from those thousands of people who live in a small room, reflect our life now, and we hope it is over by the time we normalize our life again. We feel the same thing when the pandemic hit Jakarta last year. We hope it will never come back again in the future or at least our future. The aim of this article is to deliver the same message to our board in our educational institution to focus not only in the intelligent development but also on creating the passion for helping other human get their best moment of their live. For the method, we are using indirect promotion to classes by using a small set of messages. Yet, we believe this is aligned with our personal integrity and professionalism in our daily activities as lecturer and higher education student. As a result, we hope that at the right time, we might see their cherish smile after they have their happy moment.
\end{abstract}

Keywords: Higher Education, Foster Care

\begin{abstract}
ABSTRAK
Saat ini manusia dapat menolong satu dengan yang lain terutama mereka yang dekat dalam kehidupan sehari - hari. Membeli pertolongan kepada orang lain adalah sesuatu yang sederhana, bisa dimulai dari memberikan sejumlah kecil uang sampai dengan memberikan pengalaman istimewa seumur hidup yang terjadi dalam dua hari dan satu malam. Setelah hampir dua tahun kita merasakan hidup dalam dunia yang relatif hanya sebesar kamar seperti halnya saudara kita yang tinggal di panti, sebentar lagi kita akan merasakan kebahagiaan kembali saat semua kembali normal. Kita berharap hal yang terjadi di masa lalu ini, tidak terjadi lagi di masa mendatang, atau paling tidak tidak terjadi pada kita dan orang disekitar kita. Tujuan dari artikel ini adalah untuk mencoba menyampaikan pesan yang sama dalam institusi pendidikan untuk tidak hanya berfokus pada pengembangan intelektual tetapi juga menciptakan hasrat untuk menolong sesama manusia untuk memberikan momen terbaik dalam hidup mereka. Untuk metode yang digunakan, kami ingin mencoba promosi tidak langsung untuk kelas - kelas menggunakan sejumlah pesan - pesan inti. Kami percaya, hal ini sejalan dengan integritas dan profesionalitas kami dalam menjalankan aktivitas sehari - hari baik sebagai tenaga pendidik ataupun peserta didik. Sebagai kesimpulan, kami berharap pada waktu yang tepat kami dapat kembali melihat senyum dari banyak orang setelah mereka kembali mendapatkan momen terbaik dalam hidup mereka.
\end{abstract}

Kata kunci: Perguruan Tinggi, Panti Asuhan

\section{PENDAHULUAN}

\section{Analisis Situasi}

Ada banyak cara yang dapat ditawarkan oleh perguruan tinggi mulai dari meningkatkan sumber daya manusia pada panti asuhan (Humiati \& Budiarti, 2020) sampai dengan penyuluhan kesehatan penghuni panti asuhan (Oktarianita et al, 2021). Namun, itu semua tidak lengkap tanpa santunan ke panti asuhan. Itulah sebabnya santunan berapapun besarnya sangat berharga untuk panti asuhan tersebut. Selain diperlukan untuk kebersihan dan sanitasi diri, santunan tersebut juga dapat dipergunakan untuk kebutuhan akan pendidikan maupun kebutuhan akan konsumsi pangan sehari - hari. Tentu saja bagi sebagian panti asuhan yang beruntung, ada 
Seminar Nasional Hasil Penelitian dan Pengabdian Kepada Masyarakat 2021

Pengembangan Ekonomi Bangsa Melalui Inovasi Digital Hasil Penelitian dan

Pengabdian Kepada Masyarakat

Jakarta, 21 Oktober 2021

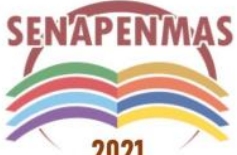

2021

tambahan kebutuhan yang dapat dipenuhi yakni kebutuhan akan rekreasi ke luar area panti asuhan.

Berbeda dengan beberapa rumah peristirahatan manula, konsep bertamasya jarang sekali terdengar dilakukan sebagai program kerja rutin sebuah panti. Walaupun demikian masih ada panti yang dikelola dengan baik tidak kehabisan akal untuk mencari sumber donasi mulai dengan berjalan dari satu rumah ibadah ke rumah ibadah lain sampai dengan bertamasya bersama dengan pengurus paling tidak setahun sekali. Tidak semua panti merasakan hal yang sama seperti ini, beberapa penghuni panti yang dikelola dengan kondisi finansial pas-pasan bahkan terlihat lebih kurus dan kurang terawat sanitasinya jika dibandingkan dengan penghuni panti sejenis yang lain.

Itulah sebabnya program pengabdian kepada masyarakat ini berfokus untuk mengusulkan beberapa program yang dapat dikembangkan oleh civitas akademika perguruan tinggi agar selain mampu meningkatkan kebahagiaan para penghuni panti asuhan di beberapa lokasi yang ada di Jakarta seperti Panti Asuhan Muslimin, Panti Asuhan Vincentius dan Panti Asuhan Putra Setia juga dapat memberikan sebuah kenangan manis yang berharga bagi para civitas akademika yang memberikan santunan tersebut. Inilah yang kemudian membuat tim pengabdian masyarakat memulai program ini dengan judul "Pemberdayaan Civitas Akademika Perguruan Tinggi untuk Memberikan Santunan ke Panti Asuhan di Jakarta".

\section{Permasalahan Mitra}

Anak - anak panti asuhan secara relatif memiliki prestasi akademik yang rendah dan pencapaian pendidikan adalah masalah praktek yang kompleks dan dengan demikian solusinya mungkin membutuhkan perubahan sistematik yang dramatis (Clemens et al, 2017). Berdasarkan Andrew et al (2021), sektor sosial juga mengalami kendala dengan diberlakukannya secara temporer Pembatasan Sosial Berskala Besar (PSBB) pada sejumlah daerah di Indonesia di masa lampau. Ini membuat kondisi mental beberapa anak panti asuhan fluktuatif. Padahal menurut Piran (2017), keadaan mental yang baik akan mendorong individu untuk memberikan respon yang selaras dengan dorongan internal maupun tuntutan lingkungannya.

Secara umum hal diatas dapat diatasi karena menurut Nafisah et al (2018) setiap orang membutuhkan kasih sayang, terutama dari orang-orang terdekat seperti orangtua dan keluarga. Dalam hal anak - anak yang berada di panti asuhan, peran orangtua dan keluarga digantikan oleh para pekerja yang bekerja dengan sepenuh hati di panti asuhan tersebut selain tentu saja donatur eksternal yang membantu secara finansial untuk kebutuhan harian mereka sehari - hari. Ini dituturkan oleh Haryanti et al (2020) menyebabkan remaja panti asuhan menganggap dirinya menjadi sumber masalah bagi lingkungan, tidak memiliki pendirian, mudah menyerah, mengalami hambatan untuk mengekspresikan emosi, terasing, kurang percaya diri, kurang aktif, mudah putus asa dan mengalami kesulitan dalam proses sosialisasi.

Selain itu juga dalam panti asuhan terdapat masalah mengenai moralitas anak. Hal ini dikarenakan menurut Somantri dan Rifai (2021) bimbingan terhadap anak itu menjadi kewajiban yang harus dilaksanakan tanpa kompromi untuk perkembangan moral sang anak itu sendiri. Ini sebabnya, dalam panti asuhan secara berkala diadakan siraman rohani dan penguatan iman yang membuat mereka relatif lebih bermoral dibandingkan dengan mereka yang terlantar di jalan. Selain hal tersebut tentu saja peran dari institusi di luar panti asuhan tersebut sangat mendukung keberlangsungan mereka seperti misalnya perguruan tinggi. Kesemua hal diatas disinyalir disebabkan karena kurangnya kondisi finansial para penghuni panti terutama dalam kondisi Pemberlakuan Pembatasan Kegiatan Masyarakat (PPKM) yang kemungkinan sebentar lagi diharapkan akan selesai. 


\section{Solusi yang Ditargetkan ingin Dicapai pada Mitra}

Untuk mengatasi permasalahan sosial, tim pengabdian masyarakat mencoba untuk mempersiapkan sistem komunikasi secara blended lewat diskusi dengan civitas akademika dari berbagai lapisan. Untuk mengatasi permasalahan budaya, tim pengabdian masyarakat mencoba untuk mensosialisasikan program yang berbeda untuk ditawarkan ke beberapa lapisan civitas akademika di perguruan tinggi. Untuk mengatasi permasalahan mutu layanan, tim pengabdian masyarakat mengusulkan untuk mengirimkan pesan ke sejumlah civitas akademika terkait setiap program yang ditawarkan ke mitra jika memungkinkan bertemu langsung dengan para penghuni panti asuhan. Untuk mengatasi permasalahan kehidupan bermasyarakat, tim pengabdian kepada masyarakat mengusulkan adanya ajakan secara pribadi terkait pentingnya memberikan donasi kepada panti asuhan yang membutuhkan.

\section{METODE PELAKSANAAN}

Tim pengabdian kepada masyakarat yang berasal dari gabungan dosen dan mahasiswa Fakultas Ekonomi \& Bisnis Universitas Tarumanagara Jakarta mencoba untuk menjalankan tahapan yang ditabulasi sebagai berikut:

Tabel 1. Tahapan Pelaksanaan Solusi

\begin{tabular}{cc}
\hline Tahap & Langkah - Langkah Pelaksanaan \\
\hline 1 & Pengadaan penjajakan pendahuluan mencari panti asuhan secara telepon. \\
\hline 2 & Pengiriman hasil ulasan dari tim pengabdian kepada panti asuhan secara daring. \\
\hline 3 & Evaluasi hasil ulasan yang dikirim oleh secara daring. \\
\hline 4 & Pengajuan artikel ilmiah ke Seminar Nasional Pengabdian Masyarakat 2021. \\
\hline 5 & Pengiriman pesan singkat ke beberapa wakil dari civitas akademika kampus. \\
\hline 6 & Pembelian bahan baku dan juga persiapan sebelum ke mitra. \\
\hline 7 & Kunjungan langsung ke beberapa mitra oleh perwakilan dosen dan mahasiswa. \\
\hline 8 & Penyelesaian proses administrasi dari pihak penyelenggara Seminar. \\
\hline 9 & Pelaksanaan presentasi artikel ilmiah di Senapenmas V 2021. \\
\hline 10 & Evaluasi akhir dari pelaksanaan Pengabdian kepada Masyarakat. \\
\hline
\end{tabular}

Adapun tempat yang berhasil dituju oleh tim Pengabdian kepada Masyarakat terdiri dari tiga buah panti asuhan pada tiga lokasi yang berbeda yakni Panti Asuhan Muslimin Jakarta di Jalan Kramat Raya Nomor 11 Jakarta Pusat, Panti Asuhan Vincentius Jakarta di Jalan Kramat Raya Nomor 134 Jakarta Pusat dan Panti Asuhan Putra Setia Jakarta yang berada dibawah naungan Yayasan Rukun Istri Sejahtera di Jalan Kramat Sentiong Nomor 51 Jakarta Pusat.

\section{HASIL DAN PEMBAHASAN}

Sehubungan dengan keterbatasan ruang dan waktu, tim pengabdian kepada masyarakat melakukan penelusuran awal secara daring sehingga hasil yang didapatkan ada kemungkinan tidak seefektif dan seefisien jika penjajakan diadakan secara luring. Walaupun demikian, tim pengabdian kepada masyarakat berhasil menelusuri 45 nama panti asuhan beserta dengan lokasi dan nomor telepon sebagai berikut: 
Tabel 3. Daftar Nama Panti Asuhan Berdasarkan Penelusuran

\begin{tabular}{|c|c|c|}
\hline Nama Panti Asuhan & Lokasi & Nomor Telepon \\
\hline Panti Sosial Asuhan Anak Balita Tunas Bangsa & Jakarta Timur & $+6221-844565$ \\
\hline Taman Asuhan Anak Pertiwi & Jakarta Pusat & $+6221-6337220$ \\
\hline Taman Asuhan Anak Tat Twan Asi & Jakarta Timur & $+6221-8626358$ \\
\hline Panti Sosial Asuhan Anak Putra Utama 1 & Jakarta Utara & $+6221-8614102$ \\
\hline Sasana Asuhan Anak Ceger & Jakarta Timur & $+6221-8447728$ \\
\hline Panti Yauma & Jakarta Barat & 0853-2000-0911 \\
\hline Panti Asuhan Guna Nanda & Jakarta Timur & $+6221-46824251$ \\
\hline Panti Asuhan Harapan Remaja & Jakarta Timur & $+6221-4890170$ \\
\hline Panti Asuhan Sanggar Kasih & Jakarta Barat & $0877-7575-9168$ \\
\hline Panti Asuhan Vincentius Putra & Jakarta Pusat & $+6221-3909733$ \\
\hline Panti Asuhan Hati Suci & Jakarta Pusat & $+6221-31934628$ \\
\hline Panti Asuhan Kasih Mulia Sejati & Jakarta Barat & $+6221-5809494$ \\
\hline Panti Asuhan Putra Setia & Jakarta Pusat & $+6221-3909882$ \\
\hline Panti Asuhan Karena Kasih & Jakarta Utara & $+6221-64714540$ \\
\hline Panti Asuhan Graha Anugrah & Jakarta Barat & $+6221-6339331$ \\
\hline Panti Asuhan Griya Asih & Jakarta Pusat & $+6221-4254561$ \\
\hline Panti Asuhan Bersinar & Jakarta Timur & $+6221-87706892$ \\
\hline Panti Asuhan Si Boncel & Jakarta Selatan & $+6221-7271014$ \\
\hline Panti Asuhan Pondok Kasih Agape & Jakarta Utara & $+6221-4406070$ \\
\hline Panti Asuhan Desa Putera & Jakarta Selatan & $+6221-7271016$ \\
\hline Panti Asuhan Tanjung Barat & Jakarta Selatan & $+6221-7818451$ \\
\hline Panti Asuhan Parapattan & Jakarta Timur & $+6221-8192165$ \\
\hline Panti Asuhan Pelayanan Kasih Bhakti Mandiri & Jakarta Timur & $+6221-8705308$ \\
\hline Panti Asuhan Yayasan Bina Sosial & Jakarta Utara & $0877-3479-8190$ \\
\hline Panti Asuhan Yos Sudarso & Jakarta Selatan & $+6221-7819091$ \\
\hline Panti Sosial Asuhan Kampung Melayu & Jakarta Selatan & $+6221-8297111$ \\
\hline Panti Asuhan Sos Desa Taruna & Jakarta Timur & $+6221-8730817$ \\
\hline Panti Asuhan Muslimin & Jakarta Pusat & $+6221-3106848$ \\
\hline Panti Asuhan Muslim Nusantara Foundation & Jakarta Selatan & $+6221-5268802$ \\
\hline Panti Asuhan Muhammadiyah Tanah Abang & Jakarta Pusat & $+6221-3142924$ \\
\hline Panti Asuhan Aisyiyah Kemayoran & Jakarta Pusat & $+6221-4203003$ \\
\hline Panti Asuhan Annajah & Jakarta Selatan & $+6221-7359229$ \\
\hline Panti Asuhan Mar'atun Shalihah & Jakarta Barat & 0822-6080-0272 \\
\hline Panti Asuhan Tebet & Jakarta Selatan & 0822-2380-8080 \\
\hline Pondok Yatim \& Dhuafa & Jakarta Barat & $+6221-584-4684$ \\
\hline Panti Asuhan Adinda & Jakarta Barat & $+6221-5450444$ \\
\hline Panti Asuhan Muhammadiyah Kembangan & Jakarta Barat & 0819-3415-1783 \\
\hline Panti Asuhan Vincentius Putra & Jakarta Pusat & $+6221-3909733$ \\
\hline Panti Asuhan Daarul Aitam & Jakarta Pusat & $+6221-3148812$ \\
\hline Panti Asuhan Dhuafa Al-Futuwwah & Jakarta Selatan & 0816-1841-784 \\
\hline Panti Asuhan Muslimin & Jakarta Pusat & $+6221-3106848$ \\
\hline Panti Asuhan Al Mubarokah & Jakarta Selatan & $+6221-7658125$ \\
\hline Panti Asuhan Chairun Nissa & Jakarta Selatan & $+6221-8304769$ \\
\hline Panti Asuhan Nurul Hasanah & Jakarta Selatan & $+6221-7343548$ \\
\hline Panti Asuhan Andalusia & Jakarta Selatan & $0812-9575-5787$ \\
\hline
\end{tabular}




\section{Pembahasan Luaran yang Diharapkan dan Dicapai}

Berdasarkan pencarian dalam waktu terbatas ditemukan 45 panti asuhan yang memiliki nomor telepon jika ditelusuri dengan mesin pencari untuk Daerah Khusus Ibukota Jakarta. Padahal berdasarkan informasi ada ratusan panti yang memiliki izin dan beberapa tidak mencantumkan nomor telepon hanya menggunakan alamat saja dan bahkan beberapa tidak memiliki akses situs khusus untuk panti tersebut. Adapun terlepas dari hal itu berikut ini adalah beberapa usulan yang diberikan kepada Civitas Akademika perguruan tinggi terkait dengan hal - hal yang dapat membantu memberikan kebahagiaan walau mungkin maksimal hanya dua hari dan satu malam kepada para pengurus dan penghuni panti tersebut:

Tabel 4. Rekomendasi untuk Memberikan Santunan

\begin{tabular}{|c|c|}
\hline Civitas Akademika & Rekomendasi \\
\hline Pimpinan Perguruan Tinggi & $\begin{array}{c}\text { Mengadakan Program Wisata } 2 \text { hari } 1 \text { malam bersama } \\
\text { Penghuni Panti Asuhan dengan menggunakan Hotel } \\
\text { Berbintang yang dilengkapi fasilitas memadai seperti } \\
\text { Kolam Renang dan sarapan menu buffet menjadi afiliasi } \\
\text { dari Perguruan Tinggi. }\end{array}$ \\
\hline Pimpinan Fakultas & $\begin{array}{l}\text { Mengadakan Program Wisata } 1 \text { hari bersama Penghuni } \\
\text { Panti Asuhan di Daerah Wisata Utama Propinsi Daerah } \\
\text { Khusus Ibukota Jakarta seperti Taman Impian Jaya } \\
\text { Ancol Paket Terusan Dunia Fantasi + Gelanggang } \\
\text { Samudera atau Taman Mini Indonesia Indah. }\end{array}$ \\
\hline Pimpinan Program Studi & $\begin{array}{l}\text { Mengadakan Program Pengabdian kepada Masyarakat } \\
\text { gabungan dosen dalam satu bidang studi ke Panti Asuhan } \\
\text { untuk mengadakan pelatihan sesuai dengan bidang } \\
\text { konsentrasi yang diampu masing - masing dosen disertai } \\
\text { makan siang bersama dengan Penghuni Panti Asuhan. }\end{array}$ \\
\hline Pimpinan Lembaga Mahasiswa & $\begin{array}{l}\text { Mengadakan Program Bakti Sosial ke salah satu Panti } \\
\text { Asuhan di Daerah Khusus Ibukota Jakarta dengan } \\
\text { menggunakan jas almamater dan juga seragam lembaga } \\
\text { mahasiswa masing - masing sebagai bagian dari peran } \\
\text { serta mahasiswa untuk kepedulian dan kepekaan sosial. }\end{array}$ \\
\hline Pimpinan Karyawan Non-Pendidik & $\begin{array}{l}\text { Mengadakan program berbagi bahan pangan dan sanitasi } \\
\text { diri ke salah satu Panti Asuhan dengan menggunakan } \\
\text { seragam Karyawan Non-Pendidik sebagai bagian dari } \\
\text { peran serta Karyawan Non-Pendidik untuk kepedulian } \\
\text { dan kepekaan sosial. }\end{array}$ \\
\hline Dosen \& Mahasiswa & $\begin{array}{l}\text { Menulis artikel ilmiah bersama - sama terkait dengan } \\
\text { Program Pengbadian kepada Masyarakat di salah satu } \\
\text { Panti Asuhan sebagai bagian dari pemenuhan Tri } \\
\text { Dharma Perguruan Tinggi bagi tenaga pengajar dan } \\
\text { Surat Keterangan Pendamping Ijazah bagi peserta didik. }\end{array}$ \\
\hline Karyawan Non-Pendidik & $\begin{array}{c}\text { Menyumbang berupa santunan yang bersifat sukarela ke } \\
\text { salah satu Panti Asuhan melalui program berbagi bahan } \\
\text { pangan dan sanitasi diri yang diusulkan oleh Pimpinan } \\
\text { Karyawan Non-Pendidik selama situasi dan kondisi } \\
\text { memungkinkan. }\end{array}$ \\
\hline
\end{tabular}




\section{KESIMPULAN DAN SARAN}

\section{Kesimpulan dari Pengabdian kepada Masyarakat}

Usulan diatas diharapkan dapat langsung diterapkan ke panti asuhan yang berhasil didapat oleh tim pengabdian kepada masyarakat. Adapun tim ini juga akan terus memantau respons dari setiap panti asuhan dan untuk beberapa panti asuhan yang kemudian merespons dengan positif, tim dari pengabdian kepada masyarakat akan bersedia untuk hadir memberikan santunan langsung di tiga panti asuhan. Di masa mendatang, artikel ini dapat dijadikan sebagai usulan singkat ke pimpinan perguruan tinggi terkait. Paling tidak dari pantauan terakhir tim PkM sudah ada beberapa pengurus panti yang memberikan respons terkait dengan hal ini walaupun dalam kondisi PPKM untuk tatap muka langsung dengan penghuni masih belum tentu dapat dilakukan.

Secara sosial, panti asuhan akan lebih memungkinkan jika civitas akademika yang melaksanakan setiap rekomendasi menjalankan hal ini apalagi seperti yang diketahui oleh Tim PKM bahwa sudah ada penghuni panti yang berhasil menempuh pendidikan tinggi di Universitas Tarumanagara secara langsung. Secara budaya, adanya kerjasama antara lembaga sosial dengan lembaga pendidikan diharapkan dapat dilanjutkan pada tahap yang lebih rutin untuk membantu menjaga sinergi dengan panti asuhan tersebut. Secara mutu layanan, jika semua rekomendasi diatas dilaksanakan, maka tim pengabdian kepada masyarakat yakin bahwa Perguruan Tinggi sudah naik tingkat dalam segi kualitas pengelolaannya. Tentu saja semua ini diharapkan akan membantu memberi kepekaan sebagai bagian dari penciptaan rasa kemanusiaan yang lebih bermanfaat lagi.

\section{Saran dari Pengabdian kepada Masyarakat}

Untuk kegiatan Pengabdian kepada Masyarakat sejenis bisa saja dilakukan dengan lebih implementatif dengan mengunjungi secara luring seluruh panti asuhan satu per satu jika dana dan waktu memadai. Hal lain yang perlu dipertimbangkan adalah adanya kemungkinan untuk mendapatkan bantuan pendanaan dari LPPM atau unit lain dalam Perguruan Tinggi untuk aktivitas Pengabdian kepada Masyarakat sejenis agar dapat menampung kegunaan dan kecocokan yang sesuai dengan target mitra yang dituju.

\section{Ucapan Terima Kasih (Acknowledgement)}

Kami berterima kasih atas bantuan dari penyelenggara Seminar Nasional Pengabdian Masyarakat 2021 yang telah memberikan kami kesempatan untuk mempresentasikan artikel kami.

\section{REFERENSI}

Andrew, R., Hastuti, R. T. \& Claudia, M. (2021). Inovasi Pengelolaan Donasi untuk Percepatan Penyaluran Bantuan kepada Panti Asuhan. Proceeding SERINA 2021, 2, 914-922.

Clemens, E. V., Helm, H. M., Myers, K., Thomas, C., \& Tis, M. (2017). The Voices of Youth Formerly in Foster Care: Perspectives on Educational Attainment Gaps. Children and Youth Services Review, 79, 65-77.

Haryanti, K, Reynaldi, E. T., Hapsari, W., Fera, P. L. \& Wijiasih, S. P. P. (2020). Efektivitas Pelatihan Komunikasi Interpersonal Terhadap Kepercayaan Diri Dan Harga Diri Pada Remaja Panti Asuhan. Efektivitas Pelatihan Komunikasi Interpersonal Terhadap Kepercayaan Diri Dan Harga Diri Pada Remaja Panti Asuhan, 1(1), 49-62.

Humiati, H., \& Budiarti, D. (2020). Peran Perguruan Tinggi Dalam Meningkatkan Sumber Daya Manusia. JMM-Jurnal Masyarakat Merdeka, 3(1), 1-7. 


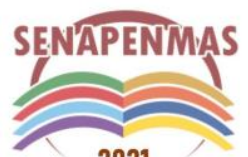

2021
Seminar Nasional Hasil Penelitian dan Pengabdian Kepada Masyarakat 2021 Pengembangan Ekonomi Bangsa Melalui Inovasi Digital Hasil Penelitian dan Pengabdian Kepada Masyarakat Jakarta, 21 Oktober 2021

Nafisah, A., Hendriyani, R., \& Martiarini, N. (2018). Hubungan antara Dukungan Keluarga dengan Self Compassion Remaja di Panti Asuhan. Intuisi: Jurnal Psikologi Ilmiah, 10(2), 160-166.

Oktarianita, O., Nurhayati, N., \& Amin, M. (2021). Edukasi Kesehatan Remaja di Panti Asuhan Bintang terampil Kota Bengkulu. Jurnal Pengabdian Masyarakat Bumi Raflesia, 4(2), 564-573.

Piran, A. Y. A., Yuliwar, R., \& Ka'arayeno, A. J. (2017). Hubungan antara Penerimaan Diri dengan Kepercayaan Diri dalam Interaksi Sosial pada Remaja Penyandang Cacat Fisik di Panti Asuhan Bhakti Luhur Kecamatan Sukun Malang. Nursing News: Jurnal Ilmiah Keperawatan, 2(1), 578-597.

Somantri, A., \& Rifai, A. (2021). Pola Pendidikan Moral di Panti Asuhan. Reslaj: Religion Education Social Laa Roiba Journal, 3(1), 70-80. 
Seminar Nasional Hasil Penelitian dan Pengabdian Kepada Masyarakat 2021

Pengembangan Ekonomi Bangsa Melalui Inovasi Digital Hasil Penelitian dan

Pengabdian Kepada Masyarakat

Jakarta, 21 Oktober 2021

(halaman kosong) 